\title{
PENGEMBANGAN PERANGKAT PEMBELAJARAN DENGAN MODEL SIKLUS BELAJAR 5E PADA MATERI KALOR UNTUK MENINGKATKAN HASIL BELAJAR SISWA
}

\author{
Kamaluddin', \\ Bambang Soebali ${ }^{2)}$ \\ Soeparman Kardi ${ }^{3)}$ \\ 1) Mahasiswa Program Studi Pendidikan Sains Program Pascasarjana Universitas Negeri Surabaya \\ ${ }^{2)}$ Dosen Program Studi Pendidikan Sains Program Pascasarjana Universitas Negeri Surabaya \\ ${ }^{3)}$ Dosen Program Studi Pendidikan Sains Program Pascasarjana Universitas Negeri Surabaya \\ e-mail: kamal.un633@gmail.com
}

\begin{abstract}
This research intents on developing learning Package with 5E model on heat to improve student learning outcomes. The research was conducted in two phases. The first phase was developing learning instrument by adapting the model of Dick \& Carey. It included analyzing the basic competencies, analyzing concepts, analyzing students, formulating learning goals, developing instruments, developing learning strategies, and compiling learning Package. The second phase was testing the instruments on 10 students of SMPN 1 Dukun Gresik. The draft of implementation in the classroom used pretest and posttest design and descriptive qualitative data analysis. Based on the result of data analysis, the research showed that learning instrument that was developed had average score of validation categorized as good. The description of the result on feasibility of lesson plans categorized as good overall. The outcomes of students' cognitive after given $5 E$ model of learning showed that all students competent, As well as students' motivation for followed $5 E$ model of learning is high. In conclusion, the learning instrument of science with $5 E$ model is decent used to improve student learning outcomes.
\end{abstract}

Keywords: teaching learning package, learning outcomes, learning cycle 5E model.

\begin{abstract}
Abstrak: Penelitian ini bertujuan mengembangkan perangkat pembelajaran dengan model $5 E$ pada materi kalor untuk meningkatkan hasil belajar siswa. Penelitian dilakukan dalam 2 tahap, yaitu tahap pertama mengembangkan perangkat pembelajaran dengan mengadaptasi model Dick \& Carey antara lain menganalisis kompetensi dasar, menganalisis konsep, menganalisis siswa, merumuskan tujuan pembelajaran, mengembangkan instrumen, mengembangkan strategi pembelajaran, serta menyusun perangkat pembelajaran. Tahap kedua mengujicobakan perangkat pembelajaran pada 10 siswa SMPN 1 Dukun Gresik. Rancangan implementasi di kelas menggunakan desain pretest dan posttest serta analisis data secara deskriptif kualitatif. Berdasarkan hasil analisis data, penelitian menunjukkan bahwa perangkat pembelajaran dan instrumen pembelajaran yang dikembangkan memiliki rata-rata skor validasi berkatagori baik. Deskripsi hasil penelitian keterlaksanaan RPP secara keseluruhan berkatagori baik. Hasil belajar kognitif siswa setelah diberikan pembelajaran dengan model $5 E$ menunjukkan bahwa semua siswa tuntas. Serta motivasi belajar siswa selama mengikuti pembelajaran model $5 E$ ditagorikan tinggi. Kesimpulan penelitian adalah perangkat pembelajaran dengan Model 5 E layak digunakan untuk meningkatkan hasil belajar siswa.
\end{abstract}

Kata Kunci: perangkat pembelajaran, hasil belajar, model siklus belajar $5 E$.

\section{PENDAHULUAN}

Setiap lembaga pendidikan telah dituntut untuk meningkatkan mutu pendidikan yang dilaksanakannya. Salah satu indikator peningkatan mutu pendidikan tersebut dapat dilihat dari peningkatan hasil belajar siswanya. Jika hasil belajar siswa baik, maka dapat dikatakan mutu pendidikan di sekolah tersebut baik, begitu pula sebaliknya. Dalam usaha peningkatan hasil belajar yaitu pemahaman konsep, psikomotor, dan afektif, guru dituntut dapat membangkitkan motivasi belajar siswa. Karena siswa yang berhasil di dalam belajarnya adalah siswa yang termotivasi untuk belajar (Nur, 2008).

Kurikulum Tingkat Satuan Pendidikan (KTSP) di sekolah yang telah berlaku sejak tahun 2006 hingga sekarang membawa konsekuensi logis terhadap proses pembelajaran fisika di SMP. Proses belajar yang diharapkan pada kurikulum ini bukan sekedar membahas materi dalam buku-buku panduan pelajaran atau menginformasikan pengetahuan kepada siswa, melainkan menekankan pada pemberian pengalaman secara langsung kepada siswa dalam upaya memahami konsep. Seperti tujuan dari pengembangan KTSP yaitu siswa mampu menerapkan pengetahuannya dalam kehidupan sehari-hari. Tujuan ini direalisasikan dengan pembelajaran yang menekankan teori dan praktek. Untuk mencapainya, sekolah tentu memerlukan guru yang sangat terampil dibidangnya, misalnya dalam pembuatan perangkat pembelajaran. Perangkat pembelajaran yang baik memiliki beberapa tujuan antara lain: dapat meningkatkan motivasi belajar siswa, dapat menguasai 
materi yang mendalam, serta dapat mengaplikasikan materi pembelajaran dalam kehidupan sehari-hari (Susanto, 2007:89).

Realitas pendidikan di lapangan banyak pendidik yang menggunakan perangkat pembelajaran yang berasal dari internet, tinggal membeli, serta tanpa upaya merencanakan, menyiapkan dan menyusun sendiri. Dengan demikian, resikonya sangat dimungkinkan jika perangkat pembelajaran tidak sesuai dengan kebutuhan peserta didik. Berdasarkan hasil wawancara dengan guru mata pelajaran di SMPN 1 Dukun Gresik diperoleh fakta bahwa sebagian besar siswa tidak semangat dalam mengikuti kegiatan belajar mengajar, dan kurang memahami konsep yang telah diajarkan sehingga tidak dapat menerapkan ilmu tersebut untuk menyelesaikan permasalahan di dunia nyata, serta hasil belajar yang diperoleh pun kurang dari kriteria ketuntasan. Fakta tersebut dibuktikan dengan: (1) Hasil ulangan harian pada setiap kompetensi dasar rata-rata hanya 40\% siswa yang tuntas. (2) Siswa kurang terampil dalam menggunakan alat-alat percobaan. (3) serta siswa kurang berminat dalam mengikuti Kegiatan Belajar Mengajar (KBM) yang dilaksanakan di kelas karena dalam pembelajaran siswa jarang dilibatkan secara langsung, dan materi yang disampaikan terkesan monoton. Hal ini disebabkan oleh beberapa hal, salah satunya perangkat pembelajaran yang didapatkan dari internet yang tidak disusun kembali untuk disesuaikan dengan kebutuhan siswa.

Salah satu model pembelajaran yang dapat dijadikan untuk mengembangkan perangkat pembelajaran yang baik yaitu model pembelajaran siklus belajar 5E. Siklus belajar 5E terdiri dari Engagement, Exploration, Explanation, Elaboration, and Evaluation. Masingmasing tahap dalam pembelajaran ini memiliki fungsi tersendiri misalnya tahap Engagement, untuk mempersiapkan siswa dalam belajar dan untuk menarik perhatian siswa sehingga termotivasi dalam melakukan kegiatan belajar mengajar (KBM). Tahap Exploration, mencari informasi atau pengetahuan dengan melakukan penyelidikan. Tahap Explanation, menjelaskan dan menganalisis informasi yang didapat dari proses penyelidikan untuk dijadikan pegangan suatu ilmu pengetahuan, tahap Elaboration, untuk mencari informasi yang lebih lanjut tentang hasil penyelidikan dari beberapa sumber sehingga didapatkan pengetahuan yang lebih banyak lagi, dan tahap yang terakhir yaitu Evaluation, menentukan pemahaman siswa yang telah dilakukan mulai dari proses Engagement, Exploration, Explanation, Elaboration (Bybee, et al, 2006:2).

Model pembelajaran siklus belajar 5E merupakan konsep belajar yang dapat membantu guru untuk mengaitkan konsep meteri pembelajaran dengan situasi kehidupan nyata sehingga siswa lebih termotivasi dalam KBM, pemberian motivasi ditemukan pada tahap engagement. Model siklus belajar 5E juga mengajarkan kepada siswa untuk menyelesaikan permasalahan secara ilmiah atau bekerja secara ilmiah, sehingga didapatkan hasil yang sesuai fakta, kemudian dibandingkan dari sisi konsep yang sudah ada. Proses belajar secara langsung seperti ini, dapat menyimpan informasi di memori jangka panjang siswa (Slavin, 2009:172).

Selanjutnya, agar tercapai tujuan pembelajaran dalam suatu model pembelajaran tersebut, maka dikembangkan suatu perangkat pembelajaran yang sesuai. Perangkat pembelajaran yang perlu dikembangkan menurut peneliti adalah Silabus, Rencana Pelaksanaan Pembelajaran (RPP), Bahan Ajar Siswa (BAS), Lembar Kerja Siswa (LKS), dan Lembar Evaluasi. Pengembangan perangkat pembelajaran adalah serangkaian proses atau kegiatan yang dilakukan untuk menghasilkan suatu perangkat pembelajaran berdasarkan teori pengembangan yang telah ada. Penyusunan Rencana Pelaksanaan Pembelajaran (RPP) harus memperhatikan prinsip dan langkah-langkah penyusunan yang sudah ditetapkan dalam Permendiknas No 41 tahun 2007 tentang Standar Proses. RPP memuat identitas mata pelajaran, Standar Kompetensi (SK), Kompetensi Dasar (KD), indikator pencapaian kompetensi, tujuan pembelajaran, materi ajar, alokasi waktu, metode pembelajaran, kegiatan pembelajaran, penilaian hasil belajar, dan sumber belajar (Depdiknas, 2006). Sedangkan materi pelajaran yang akan diajarkan dengan pembelajaran siklus belajar 5E adalah kalor. Peneliti memilih materi ini karena topik ini mempunyai banyak aplikasi dalam kehidupan sehari-hari dan sebagian besar masih banyak mengalami kesulitan dalam menyelesaian masalah yang berhubungan dengan konsep kalor terutama saat dikaitkan dengan kehidupan sehari - hari.

Penelitian ini bertujuan untuk Mengembangkan perangkat pembelajaran dengan menggunakan model $5 \mathrm{E}$ yang layak digunakan untuk meningkatkan hasil belajar siswa pada materi kalor. Hasil penelitian ini dapat bermanfaat untuk membantu guru dalam menyediakan perangkat pembelajaran yang dikembangkan dengan model siklus belajar 5E dalam rangka meningkatkan minat belajar, dan meningkatkan pemahaman konsep siswa.

\section{METODE}

Penelitian ini adalah penelitian pengembangan, perangkat pembelajaran yang dikembangkan menggunakan model pembelajaran siklus belajar 5E pada materi kalor berupa Rencana Pelaksanaan Pembelajaran (RPP), Buku Ajar Siswa (BAS), Lembar Kerja Siswa (LKS), dan Tes Hasil Belajar (THB). Penelitian ini mengacu pada model pengembangan perangkat Dick dan Carey yang dikembangkan oleh Water Dick, Lou Carey, dan James O. Carey. 
Subyek penelitian adalah perangkat pembelajaran, terdiri dari Rencana Pelaksanaan Pembelajaran (RPP), Buku Ajar Siswa (BAS), Lembar kerja Siswa (LKS), dan Tes Hasil Belajar (THB). Subyek penelitian pada tahap uji coba perangkat pembelajaran adalah siswa kelas VII di SMPN 1 Dukun Gresik. Penentuan siswa dilakukan oleh guru dengan mempertimbangkan heterogenitas gender dan homogenitas kemampuan siswa yang dilihat dari nilai ulangan harian yang diperoleh sebelumnya. Peneliti tidak melakukan intervensi langsung untuk menentukan subyek.

Prosedur pengembangan perangkat pembelajaran mengadaptasi model dari Dick and Carey. Dick dan Carey, 2001 memandang desain pembelajaran sebagai sebuah sistem dan menganggap pembelajaran adalah proses yang sistematis. Langkah-langkah pengembangan perangkat pembelajaran menurut model Dick and Carey meliputi 1) mengidentifikasi tujuan, 2) menganalisis struktur isi dan konsep, 3) anlisis siswa, 4) merumuskan tujuan pembelajaran khusus, 5) mengembangkan instrumen, 6) mengembangkan strategi pembelajaran, 7) menyusun perangkat pembelajaran, 8) validasi oleh pakar, 9) revisi I perangkat pembelajaran, 10) uji coba perangkat pembelajaran yang sudah dikembangkan dengan jumlah kelompok yang kecil, 11) merevisi kembali perangkat pembelajaran yang sudah diuji cobakan, 12) uji coba lapangan dengan menggunakan obyek penelitian yang lebih besar, 13) analisis, 14) dan menulis laporan tesis.

Tehnik-tehnik analisis data yang digunakan dalam penelitian ini adalah sebagai berikut :

\section{Analisis Validitas Perangkat Pembelajaran}

Data yang telah dikumpulkan dalam penelitian ini selanjutnya dilakukan analisis secara deskriptif kuantitatif, yaitu dengan merata-rata skor masing-masing komponen. Validasi ini dilakukan oleh validator yang kompeten di bidangnya. Hasil skor rata-rata dideskripsikan sebagai berikut:

Tabel 1. Kriteria Penskoran

\begin{tabular}{cc}
\hline Interval & Katagori Penilaian \\
\hline $\mathbf{0 , 0} \leq \mathrm{SV} \leq \mathbf{1 , 0}$ & Tidak layak \\
$\mathbf{1 , 0} \leq \mathrm{SV} \leq \mathbf{2 , 0}$ & Kurang \\
$\mathbf{2 , 0} \leq \mathrm{SV} \leq \mathbf{3 , 0}$ & Sedang \\
$\mathbf{3 , 0} \leq \mathrm{SV} \leq \mathbf{4 , 0}$ & Layak \\
$\mathbf{4 , 0} \leq \mathrm{SV} \leq \mathbf{5 , 0}$ & Sangat layak \\
\hline & (Sumber : Ratumanan \& Laurens, 2006)
\end{tabular}

Keterangan :

$\mathrm{SV}=$ Skor Validasi

Sedikit revisi jika sub komponen kelayakan RPP yang harus direvisi paling banyak $25 \%$ dari seluruh jumlah sub komponen kelayakan RPP.

Banyak revisi jika sub komponen kelayakan RPP yang harus direvisi lebih dari $25 \%$ dari seluruh jumlah sub komponen kelayakan RPP.

\section{Analisis Keterlaksanaan Sintak pembelajaran}

Penilaian terhadap keterlaksanaan sintak pengajaran langsung dilakukan oleh dua orang pengamat. Kriteria tiap fase dalam sintak yang dimaksud adalah terlaksana dan tidak terlaksana. Berdasarkan rata-rata penilaian dari dua pengamat. Adapun skala persentase untuk menentukan keterlaksanaan RPP menggunakan rumus berikut :

$$
\begin{aligned}
& R=\frac{X}{\sum X} x \mathbf{1 0 0 \%} \\
& \text { Keterangan : } \\
& \mathrm{R} \quad=\text { nilai dalam presentase } \\
& X \quad=\text { jumlah tahapan yang dilakukan }
\end{aligned}
$$

$\sum X=$ jumlah keseluruhan tahapan pembelajaran

Aspek yang diamati selanjutnya ditentukan kategori dengan rincian :

$$
\begin{array}{ll}
0-25 \%, & : \text { Tidak terlaksana } \\
26 \%-50 \%, & : \text { Terlaksana kurang } \\
51 \%-75 \%, & : \text { Terlaksana baik } \\
71 \%-100 \%, & : \text { Terlaksana sangat baik }
\end{array}
$$

(Riduwan,2010)

\section{Tehnik Pengamatan Aktivitas Siswa}

Aktivitas siswa selama pembelajaran dianalisis secara statistik deskriptif berdasarkan rata-rata hasil pengamatan dari dua pengamat. Selanjutnya dihitung presentase hasil pengamatan aktivitas siswa tersebut dan divisualisasikan dalam bentuk diagram batang. Rumus yang digunakan adalah frekuensi aktivitas siswa perkatagori yang teramati oleh pengamat dibagi jumlah aktivitas seluh siswa selama KBM berlangsung dikali 100\%. Aspek yang diamati selanjutnya ditentukan kategori dengan rincian:

$$
\begin{array}{ll}
0-25 \%, & : \text { Aktivitas siswa tidak baik } \\
26 \%-50 \%, & : \text { Aktivitas siswa kurang baik } \\
51 \%-75 \%, & : \text { Aktivitas siswa baik } \\
71 \%-100 \%, & : \text { Aktivitas siswa sangat baik }
\end{array}
$$

(Riduwan,2010)

\section{Analisis Motivasi Belajar Siswa}

Respon siswa dianalisis secara deskriptif kuantitatif dengan persentase, yang diperoleh dengan rumus :

$$
P=\frac{\sum K}{\sum N} x 100 \%
$$

Keterangan :

$$
\begin{aligned}
& \mathrm{P}=\text { nilai rata-rata dalam \% } \\
& \sum K=\text { jumlah jawaban respon } \\
& \sum N=\text { jumlah total respon }
\end{aligned}
$$

Aspek yang diamati selanjutnya ditentukan kategori dengan rincian :
$0-25 \%$,
$26 \%-50 \%$,
: Kurang baik
$51 \%-75 \%$,
: Cukup baik
$71 \%-100 \%$,
: Sangat baik 


\section{Analisis Hasil Tes Belajar Siswa}

(Riduwan,2010)

Berdasarkan data hasil pretest dan postest, kemudian dianalisis secara deskriptif kualitatif yang terdiri dari:

\section{Ketuntasan Indikator}

Ketuntasan belajar ideal untuk setiap indikator adalah $0-100 \%$, dengan batas kriteria ideal minimal $75 \%$. Sekolah dapat menetapkan kriteria ketuntasan minimal di bawah batas kriteria ideal, tetapi secara bertahap harus dapat mencapai kriteria ketuntasan ideal. Pada penelitian ini, peneliti menetapkan batas kriteria ideal suatu indikator dikatakan tuntas apabila $\geq 75 \%$ siswa mencapai ketuntasan indikator.

$$
\text { Ketuntasan Individu }=\frac{\text { Jumlah Persentase Indikator }}{\text { Jumlah Indikator }}
$$

\section{Ketuntasan Individu}

Secara individu siswa telah tuntas belajar, apabila rata-rata ketercapaian indikator yang mewakili tujuan pembelajaran memenuhi Kriteria Ketuntasan Minimal (KKM) yang ditetapkan sebesar 75\%, sedangkan pembelajaran secara klasikal dikatakan tuntas apabila $\geq 75 \%$ individu tuntas. Karena setiap indikator diukur dengan menggunakan butir soal, maka ketuntasan hasil belajar individu dapat dihitung dengan menggunakan rumus (Mulyasa, 2007) :HASIL DAN PEMBAHASAN

Data hasil penelitian pengembangan perangkat pembelajaran fisika dengan model 5E untuk meningkatkan hasil belajar siswa dipaparkan pada bab ini. Ada tiga tahapan penelitian yang telah dilakukan, yaitu tahap pengembangan perangkat pembelajaran, validasi perangkat pembelajaran, dan uji coba di kelas serta keterlaksanaannya. Berikut ini deskripsi tentang perangkat yang dikembangkan serta hasil penenlitian.

\section{Hasil Pengembangan Perangkat Pembelajaran}

Perangkat pembelajaran yang dikembangkan dengan model $5 \mathrm{E}$ digunakan untuk meningkatkan hasil belajar siswa. Perangkat pembelajaran yang dikembangkan terdiri atas: Silabus, Rencana Pelaksanaan Pembelajaran (RPP), Bahan Ajar Siswa, Lembar Kerja Siswa (LKS), dan Lembar Penilaian. Kemudian perangkat pembelajaran tersebut ditelaah oleh bapak Prof. Soeparman Kardi, M.Sc., Ph.D. selaku pembimbing dalam pengembangan perangkat dan Dr. Wasis, M.Si selaku sebagai validator dari unsur eksternal.

\section{Silabus}

Silabus yang dikembangkan memuat poin-poin sebagai berikut: judul, identitas, standar kompetensi, kompetensi dasar, materi, indikator, tujuan pembelajaran, metode belajar, penilaian, alokasi waktu, dan sumber belajar.

Hasil validasi silabus yang telah dikembangkan dalam penelitian dapat dilihat pada tabel 4.1, masingmasing aspek penilaian berkatagori sangat baik. Hal ini menunjukkan bahwa silabus yang dikembangkan sudah dapat dijadikan acuan dalam menyusun perangkat pembelajaran.

\section{Rencana Pelaksanaan Pembelajaran (RPP)}

RPP yang dikembangkan terdiri atas: identitas (nama sekolah, mata pelajaran, kelas/semester, alokasi waktu), Standar Kompetensi, Kompetensi Dasar, indikator, tujuan, model pembelajaran, dan sintaks pembelajaran. aspek penilaian RPP yang diukur meliputi: identitas RPP, perumusan tujuan pembelajaran, pemilihan model pembelajaran, pemilihan sumber belajar, kegiatan pembelajaran, serta dilengkapi kolom penilaian keterlaksanaan pembelajaran.

Menurut Vygotsky (dalam Nur \& Wikandari, 1999), pengembangan perangkat pembelajaran dapat memberikan umpan balik kepada siswa untuk meningkatkan kemampuan potensinya. Sehingga sesuai dengan pengembangan perangkat pembelajaran yang dibuat oleh peneliti, yaitu perangkat pembelajaran yang dikembangkan merupakan salah satu faktor yang menentukan tercapai atau tidaknya tujuan pembelajaran, perangkat pembelajaran yang baik akan menentukan kualitas pembelajaran. Oleh karena itu, pembuatan perangkat pembelajaran yang baik dan berkualitas harus dilakukan oleh setiap pengajar di sekolah-sekolah.

\section{Bahan Ajar Siswa (BAS)}

BAS yang dikembangkan pada penelitian ini khusus materi kalor, bahan ajar fisika kelas VII semester 2. Buku ajar ini dibuat berorientasikan pada pembelajaran konstruktivis. sehingga materi yang disusun di BAS menyediakan permasalahan-permasalahan yang berkaitan dengan kehidupan sehari-hari. sehingga siswa diharapkan lebih termotivasi untuk belajar dan mendapatkan pemahaman yang utuh (komprehensif) secara mandiri. Penilaian bahan ajar siswa meliputi aspek kelayakan isi, penyajian, kebahasaan dan fitur tambahan mendapatkan nilai rata-rata masing-masing aspek adalah 3,60; 3,60; 4,00; 3,67; dan 3,72. Hal ini menunjukkan bahwa bahan ajar siswa layak sebagai perangkat pembelajaran, berkatagori baik dan sedikit revisi.

\section{Menurut Piaget dalam Nur (2008:2-3)} konstruktivisme menekankan bahwa perubahan kognitif hanya terjadi jika konsepsi-konsepsi yang telah dipahami sebelumnya diolah melalui suatu proses ketidakseimbangan dalam upaya memahami informasiinformasi baru. Hal ini sesuai dengan BAS yang telah 
kembangkan, BAS mengacu pada pembelajaran konstruktivis dengan menyediakan permasalahan di kehidupan sehari-hari. Sehingga diharapkan dengan permasalahan yang disajikan siswa tergugah untuk mencari tahu informasi yang lebih lanjut untuk mendapatkan pemahaman sendiri secara utuh.

\section{Lembar Kerja Siswa (LKS)}

Aspek yang dinilai pada lembar validasi LKS meliputi: syarat-syarat didaktif, kelayakan isi, prosedur atau langkah-langkah percobaan, dan pertanyaan. Berdasarkan hasil validasi LKS yang telah dikembangkan dalam penelitian ini, dapat dilihat pada tabel 4.5. hasil yang diperoleh menunjukkan bahwa skor rata-rata validasi LKS masing-masing aspek sebesar 4,00; 4,00; 4,00; serta 3,67. Skor rata-rata keempat aspek diperoleh sebesar 3,92 dengan kategori sangat baik, sehingga LKS dapat digunakan dalam pembelajaran.

\section{Tes Hasil Belajar (THB)}

Tes hasil belajar yang dikembangkan terdiri dari tes hasil belajar kognitif, tes hasil belajar afektif, dan tes hasil belajar psikomotor. Masing-masing ranah tes hasil belajar memiliki instrumen yang berbeda yaitu; THB kognitif menggunakan instrumen tes soal pilihan ganda, THB afektif menggunakan instrumen lembar pengamatan afektif siswa, serta THB psikomotor menggunakan instrumen lembar pengamatan psikomotor siswa. Hasil validasi lembar tes hasil belajar kognitif yang meliputi ranah materi, ranah konstruksi, dan ranah bahasa diperoleh nilai rata-rata 4,00 dengan katagori valid. Skor ini menunjukkan bahwa instrumen tes hasil belajar kognitif yang telah dikembangkan dapat digunakan dalam pembelajaran.

Hasil validasi THB afektif diperoleh hasil validasi lembar tes hasil belajar afektif yang meliputi kesesuaian aspek yang diamati dengan standart kompetensi, kompetensi dasar, dan indikator; mencakup lima aspek yaitu: Receiving, Responding, Valuing, Organizing, dan Characterizing by a value complex; kesesuaian aspek yang diamati dengan skala penilaian; aspek yang diamati dapat didefinisikan dengan jelas; aspek yang dinilai mudah diamati. Skor rata-rata yang diperoleh dari masing-masing aspek antara lain 4,00;4,00;3,50; 4,00; 4,00. Rata-rata skor secara keseluruhan sebesar 3,90 dengan sangat baik. Skor ini menunjukkan bahwa instrumen tes hasil belajar afektif yang telah dikembangkan dapat digunakan dalam pembelajaran.

Hasil validasi THB psikomotor yang meliputi kesesuaian aspek yang diamati dengan standart kompetensi, kompetensi dasar, dan indikator; mencakup lima ranah yaitu: Imitation, Manipulation, Precision, dan Articulation; kesesuaian aspek yang diamati dengan skala penilaian; aspek yang diamati dapat didefinisikan dengan jelas; serta aspek yang dinilai mudah diamati. Skor ratarata yang diperoleh dari masing-masing aspek antara lain 4,$00 ; 4,00 ; 4,00 ; 4,00 ; 4,00$. Rata-rata skor secara keseluruhan sebesar 4,00 dengan sangat baik. Skor ini menunjukkan bahwa instrumen tes hasil belajar psikomotor yang telah dikembangkan dapat digunakan dalam pembelajaran. Berdasarkan ketiga ranah yaitu kognitif, afektif, dan psikomotor didapatkan hasil belajar. Proporsi masing-masing ranah pembelajaran sebesar 50\% THB kognitif, 30\% THB afektif, dan 20\% THB psikomotor.

Lembar penilaian hasil belajar adalah salah satu dari instrumen penelitian. Instrumen penelitian berfungsi untuk mempermudah mengumpulkan data sehingga hasil penelitian lengkap, sistematis, dan lebih mudah diolah (Suharsimi Arikunto, 2006). Instrumen dengan validitas baik memungkinkan data penelitian bersifat baik dan dapat dipercaya.

Instrumen penilaian hasil belajar yang telah dikembangkan dinilai kualitasnya dari kelayakannya. Aspek kelayakan menggambarkan kemampuan THB untuk mengevaluasi apa yang seharusnya dievaluasi (Ratumanan, 2011). Validitas yang digunakan pada penelitian pengembangan ini adalah validitas teoretik, dimana untuk mengetahui validitas THB dipercayakan pada pertimbangan pakar dari validator. Hasil dari validasi dari validator menyatakan bahwa THB yang telah dikembangkan valid dan layak digunakan sebagai alat untuk mengukur hasil belajar siswa.

\section{Angket Motivasi Belajar (AMB)}

Angket motivasi belajar yang dikembangkan mengukur kriteria dan kondisi yang meliputi: perhatian (Attention), relevansi (Relevance), percaya diri (Confidence), dan kepuasan (Satisfaction).

Hasil angket motivasi belajar siswa yang meliputi aspek keterkaitan indikator dengan tujuan, kesesuaian pernyataan dengan indikator, dan bahasa yang digunakan mendapatkan nilai rata-rata sebesar 3.60. Skor ini menunjukkan bahwa angket motivasi belajar siswa yang dikembangkan berkatagori baik dan sedikit revisi, serta angket motivasi belajar siswa ini dinyatakan layak sebagai alat ukur hasil pembelajaran. Menurut Suharsimi Arikuto (2006:160) instrumen penelitian adalah perangkat yang digunakan untuk mendapatkan atau mengumpulkan data, agar penelitian lebih mudah dan hasilnya lebih baik, lengkap dan sistematis, sehingga hasil yang didapatkan lebih mudah diolah. Oleh karena itu, instrumen dengan katagori validasi baik, maka akan menjadi layak digunakan untuk memperoleh data penelitian.

Keterlaksanaan Rencana Pelaksanaan Pembelajaran (RPP) 
Hasil Pengamatan Keterlaksanaan Pembelajaran di Kelas VII-A secara keseluruhan didapatkan nilai prosentase pada pertemuan pertama sebesar 93,6\%; nilai prosentase pada pertemuan kedua sebesar 95\%, serta nilai prosentase pada pertemuan ketiga sebesar 97\%. Sehingga nilai rata-rata prosentase ketiga pertemuan tersebut sebesar 95,2\%.

Hasil Pengamatan Keterlaksanaan Pembelajaran di Kelas VII-B secara keseluruhan didapatkan nilai prosentase pada pertemuan pertama sebesar $92,5 \%$; nilai prosentase pada pertemuan kedua sebesar $96 \%$, serta nilai prosentase pada pertemuan ketiga sebesar 97,5\%. Rekapitulasi perhitungan keterlaksanaan RPP dapat dilihat pada Lampiran 14b. Prosentase keterlaksanaan Rencana Pelaksanaan Pembelajaran (RPP) sebesar 95,2\%. Dengan demikian dapat dikatakan bahwa instrumen yang dikembangkan untuk pengamatan keterlaksanaan RPP dikategorikan sangat baik karena berada di atas $75 \%$.

Menurut Borich (1994) dalam Ibrahim (2005), penentuan instrumen pembelajaran dikatagorikan baik dan dapat digunakan untuk kegiatan pembelajaran bila nilai reabilitasnya lebih besar atau sama dengan $75 \%$. Oleh karena itu, instrumen pengamatan keterlaksanaan pembelajaran yang dikembangkan oleh peneliti termasuk katagori baik dan layak digunakan sebagai lembar pengamatan.

\section{Aktivitas Siswa Selama Proses Pembelajaran}

Nilai 1 sampai 8 di sisi kanan dalam grafik 1 merupakan bentuk aktivitas siswa yang diamati, 1) Mendengarkan penjelasan guru, 2) Melakukan interaksi dengan guru, 3) Berdiskusi, Mendengarkan/memperhatikan teman atau guru, 5) Mengemukakan pendapat, 6) Melakukan pengamatan,

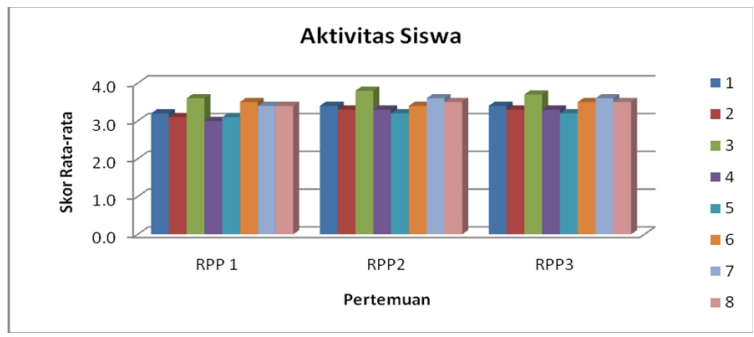

merencanakan percobaan, dan melakukan percobaan, 7) Mengajukan pertanyaan atau gagasan, 8) Bekerjasama. Grafik 1. Aktivitas Siswa

Aktivitas siswa mendeskripsikan tingkat motivasi siswa selama pembelajaran. Semakin aktif siswa mengikuti tahapan-tahapan pembelajaran, menunjukkan semakin tinggi motivasi siswa terhadap model pembelajaran yang digunakan. Skor pengamatan aktivitas yang cukup tinggi tersebut menunjukkan bahwa pembelajaran model 5E menyenangkan siswa. Menurut Karplus (1967) pembelajaran dengan menyajikan fenomena secara langsung dapat menarik motivasi belajar siswa, kemudian dalam menyelesaikan permasalahan tersebut, siswa melakukan observasi atau percobaan untuk menemukan pemahaman mereka sendiri. Pembelajaran secara langsung seperti itu dapat membantu siswa untuk memahami suatu konsep secara utuh dan mendalam. Oleh karena itu, aktivitas siswa selama pembelajaran dengan model 5E dapat membangkitkan motivasi belajar siswa, serta dapat dinyatakan aktivitas siswa selama mengikuti kegiatan belajar mengajar adalah aktif.

Menurut Auliya \& Supriati (2009) penerapan pembelajaran siklus belajar menunjukkan bahwa model pembelajaran siklus belajar 5E dapat meningkatkan aktivitas dan hasil belajar siswa. Serta dikuatkan dari penelitian Hanuscin \& Lee (2007), penelitiannya berjudul "Using a Learning Cycle Approach to Teaching the Learning Cycle to Preservice Elementary Teacher". Penerapan pembelajaran learning cycle dapat meningkatkan aktivitas belajar sehingga membantu dalam memahami suatu konsep. Oleh karena itu dapat disimpulkan bahwa aktivitas siswa selama pembelajaran dengan menggunakan perangkat pembelajaran yang dikembangkan dengan model 5E dapat meningkatkan aktivitas belajar siswa.

\section{Ketuntasan Hasil Belajar}

Ketuntasan hasil belajar ditinjau dari tiga ranah yaitu kognitif, afektif dan psikomotor. Ketiga ranah tersebut mempunyai proporsi masing-masing, ranah kognitif sebesar $50 \%$, ranah afektif $30 \%$, dan ranah psikomotor $20 \%$. Ketuntasan hasil belajar kognitif dapat dianalisis melalui aspek ketuntasan indikator dan ketuntasan individu, untuk mengetahui ketuntasan hasil belajar siswa, maka dilakukan tes dalam bentuk tes pilihan ganda. Tes hasil belajar kognitif dilakukan untuk mengukur ketercapaian kompetensi siswa ranah kognitif sesuai dengan indikator. Pada penelitian ini, pemberian tes dilakukan sebanyak dua kali, yaitu tes awal (pretest) dan tes akhir (posttest). Tingkat kesulitan soal antara tes awal dan tes akhir adalah sama. Hal ini mempunyai maksud bahwa perangkat pembelajaran dengan model 5E mempunyai pengaruh positif atau tidak kepada peserta didik.

Ketuntasan indikator pembelajaran diperoleh bahwa hasil pretest tidak satu pun indikator yang tuntas mulai dari indikator pertama sampai indikator ke empat belas, hal ini dikarenakan jumlah siswa yang tuntas untuk setiap indikator masih kurang dari $75 \%$. Ketuntasan indikator maksimal yang diperoleh pada waktu pretest hanya sebesar 53\%, Sedangkan hasil posttest setelah dilaksanakan pembelajaran dengan menggunakan perangkat pembelajaran model $5 \mathrm{E}$ semua indikator tuntas. Sehingga dapat dikatakan bahwa penggunaan perangkat pembelajaran yang dikembangkan dengan model $5 \mathrm{E}$ berpengaruh positif terhadap ketuntasan indikator pembelajaran. Hal ini sesuai dengan penelitian dari Qarareh (2012), dalam penelitiannya menemukan bahwa ada perbedaan setelah menggunakan model learning cycle dengan model pembelajaran tradisional, pembelajaran dengan model learning cycle berpengaruh positif hasil belajar siswa. Didukung penelitian dari Utami (2011), dalam penelitiannya menemukan bahwa penerapan siklus belajar 5E disertai LKS dapat 
meningkatkan kualitas proses dan hasil belajar. Serta didukung dengan teori Ausubel dalam Nur (2008:50) bahwa belajar adalah suatu proses belajar dengan menghubungkan informasi atau konsep yang telah dimiliki oleh siswa. Belajar bermakna terjadi bila siswa menghubungkan fenomena atau konsep yang dipelajari ke dalam struktur pengetahuan mereka.

Penilaian psikomotor dilakukan pada waktu proses kegiatan belajar mengajar berlangsung. Data psikomotor untuk kelas VII-A dan VII-B dapat dilihat bahwa kemampuan psikomotor siswa yang diamati adalah aspek P1, P2, P3, dan P4. Keempat aspek ini adalah imitation, manipulation, precision, dan articulation. Pada pertemuan pertama kemampuan psikomotor siswa kelas VII-A maupun kelas VII-B menunjukkan nilai akhir di atas $66 \%$. Pada pertemuan kedua mengalami peningkatan yaitu kemampuan psikomotor siswa kelas VII-A maupun kelas VII-B menunjukkan nilai akhir di atas $70 \%$. Serta pada pertemuan ketiga kemampuan psikomotor siswa kelas VII-A maupun kelas VII-B menunjukkan nilai akhir di atas $70 \%$.

Menurut Aryulina (2009), dalam penelitiannya menemukan bahwa setelah menerapkan model 5E, keterampilan inkuiri siswa siswa secara keseluruhan meningkat. Didukung dengan penelitian dari Indah, Fauziah, \& Suryawati (2012), dalam penelitiannya menemukan bahwa penerapan model pembelajaran siklus belajar (learning cycle) dapat meningkatkan motivasi belajar dan sikap ilmiah siswa. Oleh karena itu, pembelajaran dengan menggunakan perangkat pembelajaran model $5 \mathrm{E}$ berpengaruh positif terhadap aspek psikomotor.

Penilaian afektif dilakukan pada waktu proses kegiatan belajar mengajar berlangsung. Tujuan ranah afektif berhubungan dengan hierarki perhatian, sikap, penghargaan, nilai, perasaan, dan emosi (Jarolimek dan Foster dalam Dimyati dan Mudjiono, 2006:202). Data afektif untuk kelas VII-A dan VII-B pada pertemuan pertama dapat dilihat pada tabel 4.24. Kemampuan afektif siswa yang diamati adalah aspek A1, A2, A3, A4, dan A5. Keempat aspek ini adalah Receiving, Responding, Valuing, Organizing, dan Characterizing by a value complex. Pada pertemuan pertama kemampuan psikomotor siswa kelas VII-A maupun kelas VII-B menunjukkan nilai akhir di atas $74 \%$. Pada pertemuan kedua kemampuan psikomotor siswa kelas VII-A maupun kelas VII-B menunjukkan nilai akhir di atas 74\%. Dan pada pertemuan ketiga kemampuan afektif siswa kelas VII-A maupun kelas VII-B menunjukkan nilai akhir di atas $74 \%$. Hal ini berarti penggunaan perangkat pembelajaran dengan model $5 \mathrm{E}$ berpengaruh positif terhadap aspek afektif.

Hasil belajar siswa dihitung berdasarkan tiga domain yaitu domain kognitif, domain psikomotor, dan domain afektif (Sudjana, 1991:3). Menurut Jarolimek dan Foster dalam Dimyati dan Mudjiono (2006:202) bahwa tujuan ranah kognitif berhubungan dengan ingatan atau pengenalan terhadap pengetahuan dan informasi, serta pengembangan keterampilan intelektual. Tujuan ranah afektif berhubungan dengan hierarki perhatian, sikap, penghargaan, nilai, perasaan, dan emosi. Tujuan ranah psikomotor berhubungan dengan keterampilan motorik, manipulasi benda atau kegiatan yang memerlukan koordinasi saraf dan koordinasi badan.

Data hasil belajar untuk kelas VII-A dan VII-B dapat dilihat pada tabel 4.27. Perhitungan nilai akhir berpatokan kepada proporsi nilai masing-masing domain, domain kognitif dikalikan lima, domain psikomotor dikalikan dua, dan domain afektif dikalikan tiga. Hasil dari ketiga domain dijumlahkan kemudian dibagi sepuluh, maka didapatkan nilai akhir masing-masing siswa.

Nilai akhir dari hasil belajar 30 siswa kelas VII-A dan VII-B, ternyata rata-rata siswa mendapatkan nilai akhir di atas 75. Hal ini menunjukkan bahwa semua siswa yang dijadikan obyek penelitian pengembangan perangkat pembelajaran dengan model $5 \mathrm{E}$ adalah tuntas atau kompeten. Karena Kriteria Ketuntasan Minimal (KKM) adalah 75. Hal ini sesuai dengan penelitian empirik Auliya \& Supriati (2009), dalam penelitiannya menunjukkan bahwa model pembelajaran siklus belajar 5E dapat meningkatkan aktivitas dan hasil belajar siswa. Serta didukung penelitian dari Sayuti, Rosmaini, \& Andayannhi (2012), dalam penelitiannya menunjukkan bahwa penerapan model pembelajaran learning cycle $5 \mathrm{E}$ dapat meningkatkan sikap ilmiah dan hasil belajar siswa.

\section{Motivasi Belajar Siswa}

Tabel 2. Persentase Motivasi Siswa

\begin{tabular}{|c|c|c|c|c|c|}
\hline \multirow[b]{2}{*}{ Sis. } & \multicolumn{4}{|c|}{ Motivasi } & \multirow[b]{2}{*}{ Motivasi } \\
\hline & Perhatian (\%) & $\begin{array}{l}\text { Releva } \\
\mathrm{nsi}(\%)\end{array}$ & $\begin{array}{l}\text { Percaya } \\
\text { Diri (\%) }\end{array}$ & $\begin{array}{c}\text { Kepuasan } \\
(\%)\end{array}$ & \\
\hline 1 & 86,67 & 80,00 & 86,67 & 93,33 & 86,67 \\
\hline 2 & 80,00 & 80,00 & 86,67 & 86,67 & 83,33 \\
\hline 3 & 80,00 & 80,00 & 86,67 & 86,67 & 83,33 \\
\hline 4 & 73,33 & 80,00 & 86,67 & 93,33 & 83,33 \\
\hline 5 & 73,33 & 80,00 & 86,67 & 73,33 & 78,33 \\
\hline 6 & 80,00 & 93,33 & 86,67 & 73,33 & 83,33 \\
\hline 7 & 80,00 & 80,00 & 86,67 & 80,00 & 81,67 \\
\hline 8 & 80,00 & 80,00 & 80,00 & 86,67 & 81,67 \\
\hline 9 & 86,67 & 86,67 & 86,67 & 93,33 & 88,33 \\
\hline 10 & 86,67 & 86,67 & 86,67 & 86,67 & 86,67 \\
\hline 11 & 80,00 & 93,33 & 86,67 & 80,00 & 85,00 \\
\hline 12 & 93,33 & 86,67 & 86,67 & 73,33 & 85,00 \\
\hline 13 & 86,67 & 93,33 & 86,67 & 80,00 & 86,67 \\
\hline 14 & 93,33 & 93,33 & 86,67 & 80,00 & 88,33 \\
\hline 15 & 86,67 & 93,33 & 93,33 & 80,00 & 88,33 \\
\hline 16 & 86,67 & 86,67 & 93,33 & 86,67 & 88,33 \\
\hline 17 & 86,67 & 86,67 & 73,33 & 86,67 & 83,33 \\
\hline 18 & 86,67 & 86,67 & 80,00 & 86,67 & 85,00 \\
\hline 19 & 86,67 & 100,0 & 86,67 & 86,67 & 90,00 \\
\hline 20 & 93,33 & 86,67 & 66,67 & 86,67 & 83,33 \\
\hline 21 & 80,00 & 86,67 & 93,33 & 80,00 & 85,00 \\
\hline 22 & 80,00 & 86,67 & 73,33 & 86,67 & 81,67 \\
\hline 23 & 86,67 & 86,67 & 73,33 & 80,00 & 81,67 \\
\hline 24 & 80,00 & 86,67 & 80,00 & 80,00 & 81,67 \\
\hline 25 & 80,00 & 86,67 & 80,00 & 73,33 & 80,00 \\
\hline 26 & 73,33 & 86,67 & 80,00 & 86,67 & 81,67 \\
\hline 27 & 73,33 & 80,00 & 86,67 & 80,00 & 80,00 \\
\hline 28 & 80,00 & 86,67 & 80,00 & 86,67 & 83,33 \\
\hline 29 & 86,67 & 86,67 & 80,00 & 86,67 & 85,00 \\
\hline 30 & 86,67 & 80,00 & 80,00 & 80,00 & 81,67 \\
\hline $\begin{array}{c}\text { Rata } \\
(\%)\end{array}$ & 83,11 & 86,2 & 83,6 & 83,33 & \\
\hline
\end{tabular}
mengetahui respon siswa terhadap penggunaan perangkat pembelajaran dengan model $5 \mathrm{E}$ yang telah dilaksanakan. Cara mengukur motivasi belajar peneliti menggunakan instrumen dalam bentuk angket motivasi. Angket 
motivasi dibagikan kepada siswa setelah melaksanakan kegiatan belajar mengajar, serta menyelesaikan posttest.

Hasil motivasi belajar siswa dapat dilihat pada tabel 4.28. Berdasarkan tabel 4.28 ada 4 kriteria dalam penilaian motivasi belajar siswa yaitu perhatian, relevansi, percaya diri, dan kepuasan. Hasil angket motivasi siswa didapatkan persentase tiap-tiap kriteria sebesar 83,11\%; $86,22 \% ; 83,60 \%$; dan $83,33 \%$. Sedangkan nilai rata-rata persentase motivasi belajar masing-masing siswa ratarata di atas $75,00 \%$.

Penelitian ini didukung dengan penelitian empirik dari Indah, Fauziah, \& Suryawati (2012), dalam penelitiannya menunjukkan bahwa penerapan model pembelajaran siklus belajar (learning cycle) dapat meningkatkan motivasi belajar. Oleh karena itu, penelitian pengembangan perangkat pembelajaran dengan menggunakan model $5 \mathrm{E}$ dapat membangkitkan motivasi belajar siswa.

\section{SIMPULAN}

Berdasarkan temuan penelitian yang diperoleh, maka dapat disimpulkan bahwa perangkat pembelajaran dengan menggunakan model 5E layak digunakan untuk meningkatkan hasil belajar siswa pada materi kalor.

\section{SARAN}

Dari hasil penelitian yang diperoleh, maka peneliti memberikan saran agar penelitian berikutnya lebih: Perlu dilakukan penelitian lanjutan untuk mendapatkan masukan demi menyempurnakan perangkat pembelajaran pokok bahasan kalor dengan model siklus belajar $5 \mathrm{E}$ untuk melatihkan sikap ilmiah dalam menyelesaikan permasalahan.

\section{DAFTAR PUSTAKA}

Akar. (2012). "Effectiveness of 5E Learning Cycle Model on Students' Understanding of Acid-Base Concepts". Jurnal Pendidikan. Vol. 15 No. 9 PP 156-199.

Arifin, Z. 2012. Evaluasi Pembelajaran. Bandung:PT Remaja Rosdakarya.

Aryulina, D. (2009). "Implementation of 5E Learning Cycle to Increase Students' Inquiry Skills and Biology Understanding”. Jurnal Kependidikan. Vol. 12 No. 5 PP. 30-150.

Auliyah, A., \& Supriati. (2009). "The Implementation of Cycle Instructional by STAD Setting to Student of XI IPA SMAN 1 Sungguminasa”. Jurnal Chemical. Vol. 10 No. 4 PP. 164-199.

Bybee, R.W., et al. 2006. The BSCS 5E Instructional Model: Origins, Effectiveness, and Applications. 5412 Mark Dabling Boulevard: Cororado Springs CO 80918.

Bybee, R.W., et al. 2006. The BSCS 5E Instructional Model: Origins, and Effectiveness. A Report Prepared for the Office of Science Educational National Institutes of Health. 5415 Mark Dabling Boulevard: Cororado Springs CO 80918.
Depdiknas. 2006. Kurikulum Tingkat Satuan Pendidikan. Jakarta:Depdiknas.

Dick, W. \& Carey, L. 2001. The Systematic Design of Instruction, Third Edition. New York: Harper Collins Publishers.

Duran, E., et al. 2011. A Learning Cycle for All Students. Modifying the 5E Instructional Model to Address the Needs of all Learners. SC Link www.scilinks.org.

Nur, M. 2008. Pemotivasian Siswa Untuk Belajar. Surabaya:Universitas Negeri Surabaya Pusat Sains dan Matematika Sekolah.

Mulyasa, E. 2007. Kurikulum Tingkat Satuan Pendidikan. Bandung: Remaja Rosdakarya.

Ratumanan, T.G,. \& Laurens. (2003). Evaluasi Hasil Belajar yang Relevan dengan Kurikulum Berbasis Kompetensi(Tesis magister pendidikan tidak dipublikasikan). Universitas Negeri Surabaya.

Riduwan. 2002. Skala Pengukuran Variabel-Variabel Penelitian. Bandung:Alfabeta.

Slavin, R. E. 2009. Educational Psychology: Theory and Practice 9 th ed. New Jersey: Pearson Education Inc. Sudjana, N. 1991. Penilaian Hasil Proses Belajar Mengajar. Bandung : Rosdakarya. 